\title{
Mechanization Gap and Assessment of Farm Mechanization Requirement for Each Operation in Different Crops
}

\author{
P. Nagarjuna Reddy* and Jagadeesh G. Angadi \\ ${ }^{1}$ Department of Agricultural Extension Education, UAS, Dharwad-580005, India \\ *Corresponding author
}

\section{A B S T R A C T}

\begin{tabular}{|l|}
\hline Ke y w o r d s \\
Mechanization gap, \\
Paddy, Maize and \\
pigeon pea
\end{tabular}

\section{Introduction}

The farming scenario of Indian agriculture is changing day by day. The Indian scenario relating to use of farm machineries in various region differ significantly from each other. The use of machine in farming greatly depends on the soil type and the crop grown in the particular soil. Based on such argument many research and development agencies impart in development of soil and crop specific farm machineries and implements in India. The mechanization refers as the use of farm machineries in crop production operations as land preparation, residue management, plant protection, harvesting, threshing of crop and use of power for the various operation viz., irrigation, etc. (Karale et al., 2008). The adoption of machine in farming operation is increasing day by day as it resulted in saving of cost of production and increasing net income of the farmers (Singh, 2006). An attempt was made to find the gap of farm mechanization with a view to suggest the future requirement of mechanization.

\section{Materials and Methods}

The present study was conducted in Karnataka during the year 2016-17. Based on cropping pattern thee districts Uttar Kannada, Belgavi and Vijayapura were selected for paddy, maize and pigeon pea crops respectively. From each district two taluks were selected and from each taluk two villages were selected. From each village 20 farmers were 
selected comprising 10 large farmers and 10 small farmers using stratified random sampling thus making a total of 240 as the sample size. Personal interview method was followed for data collection using a interview schedule developed for the study. Statistical tools Frequency and percentage have been used for the study.

\section{Mechanization gap}

Mechanization gap is the difference between the required number of farm machinery/equipments and the actual number of farm machinery/equipments available.

\section{Farm mechanization requirement}

The mechanization requirement of study area was determined considering the machinery and mechanical power utilized over the land cultivated. The mechanization requirement has been found out with as follows:

$\mathrm{WC} \times \mathrm{TA}$

Farm Mechanization Requirement: TH

Where,

WC = Working capacity of machinery/equipment per ha

$\mathrm{TA}=$ Total area of the cultivated land

$\mathrm{TH}=$ Total no. of hours the operation was performed in a season

\section{Results and Discussion}

Mechanization gap and assessment of farm mechanization requirement for each operation

The farm machinery requirement and gap was assessed in paddy, maize and pigeon pea for the sample of 80 farmers each. Based on working capacity of implement/machinery per acre, total cultivated land area and total number of hours the operation was performed in a season, requirement of farm implement/machinery was calculated.

Mechanization gap and requirement of farm machinery for each operation is presented in Table 1. In paddy, equipment-wise gap in land preparation operation was 25.00 per cent, 64.70 per cent and 43.75 per cent that amounts to requirement of $5 \mathrm{M} \mathrm{B}$ ploughs, 11 cultivators, 7 rotovators. In sowing/transplanting operation, the gap was 37.50 per cent and 80.00 per cent that amounts to requirement of 3 seed-cum-fertilizer drills and 7 paddy transplanters. The gap was 100.00 per cent and 77.77 per cent that amounts to requirement of 4 combine harvesters and 7 paddy reapers in harvesting operation. While, in threshing, the gap was 33.33 per cent that amounts to requirement of 2 multicrop threshers.

In maize, equipment-wise gap in land preparation was 23.00 per cent, 50.00 per cent, 33.33 per cent and 25.00 per cent that amounts to requirement of $6 \mathrm{M} \mathrm{B}$ ploughs, 11 cultivators, 7 rotovators and 4 disc harrows. In sowing operation, the gap was 31.25 per cent that amounts to requirement of 5 seed-cumfertilizer drills. The gap was 100.00 per cent that amounts to requirement of 5 combine harvesters in harvesting operation. While, in threshing operation, the gap was 12.50 per cent that amounts to 1 multicrop threshers.

Equipment-wise gap in land preparation was 8.69 per cent, 36.84 per cent, 66.66 per cent and 35.71 per cent that amounts to requirement of $2 \mathrm{M}$ B ploughs, 7 cultivators, 12 rotovators and 5 disc harrows in pigeon pea. In sowing operation, the gap was 35.71 per cent that resulted in a requirement of 5 seed-cum-fertilizer drills. The gap was 100.00 per cent that amounts to requirement of 4 combine harvesters in harvesting operation. While, in threshing operation, the gap was 28.57 per cent that resulted in a requirement of 2 multicrop threshers. 
Int.J.Curr.Microbiol.App.Sci (2018) 7(12): 1213-1216

Table.1 Mechanization gap and farm machinery/equipment requirement

\begin{tabular}{|c|c|c|c|c|c|c|c|c|c|c|c|}
\hline \multirow{2}{*}{$\begin{array}{l}\text { Sl. } \\
\text { No. }\end{array}$} & \multirow[t]{2}{*}{ Operation } & \multirow{2}{*}{$\begin{array}{l}\text { Farm } \\
\text { machinery } \\
\text { and } \\
\text { equipment }\end{array}$} & \multicolumn{3}{|c|}{ Paddy } & \multicolumn{3}{|c|}{ Maize } & \multicolumn{3}{|c|}{ Pigeon pea } \\
\hline & & & Required & Available & $\begin{array}{c}\text { Gap } \\
\text { F }(\%)\end{array}$ & Required & Available & $\begin{array}{c}\text { Gap } \\
\text { F (\%) }\end{array}$ & Required & Available & $\begin{array}{c}\text { Gap } \\
\text { F }(\%)\end{array}$ \\
\hline \multirow[t]{5}{*}{1.} & \multirow{5}{*}{$\begin{array}{l}\text { Land } \\
\text { preparation }\end{array}$} & M B Plough & 20 & 15 & $\begin{array}{c}5 \\
(25.00)\end{array}$ & 26 & 20 & $\begin{array}{c}6 \\
(23.00)\end{array}$ & 23 & 21 & $\begin{array}{c}2 \\
(8.69)\end{array}$ \\
\hline & & Cultivator & 17 & 6 & $\begin{array}{c}11 \\
(64.70)\end{array}$ & 22 & 11 & $\begin{array}{c}11 \\
(50.00)\end{array}$ & 19 & 12 & $\begin{array}{c}7 \\
(36.84)\end{array}$ \\
\hline & & Rotovator & 16 & 9 & $\begin{array}{c}7 \\
(43.75)\end{array}$ & 21 & 14 & $\begin{array}{c}7 \\
(33.33)\end{array}$ & 18 & 6 & $\begin{array}{c}12 \\
(66.66)\end{array}$ \\
\hline & & Disc harrow & 14 & 7 & $\begin{array}{c}7 \\
(50.00)\end{array}$ & 16 & 12 & $\begin{array}{c}4 \\
(25.00)\end{array}$ & 14 & 9 & $\begin{array}{c}5 \\
(35.71)\end{array}$ \\
\hline & & Cage wheel & 10 & 5 & $\begin{array}{c}5 \\
(50.00)\end{array}$ & - & - & & - & - & \\
\hline \multirow[t]{2}{*}{2.} & \multirow[t]{2}{*}{$\begin{array}{l}\text { Sowing/ } \\
\text { transplanting }\end{array}$} & $\begin{array}{l}\text { Seed-cum- } \\
\text { fertilizer } \\
\text { drill }\end{array}$ & 8 & 5 & $\begin{array}{c}3 \\
(37.50)\end{array}$ & 16 & 11 & $\begin{array}{c}5 \\
(31.25)\end{array}$ & 14 & 9 & $\begin{array}{c}5 \\
(35.71)\end{array}$ \\
\hline & & $\begin{array}{l}\text { Paddy } \\
\text { transplanter }\end{array}$ & 10 & 2 & $\begin{array}{c}8 \\
(80.00)\end{array}$ & - & - & & - & - & \\
\hline \multirow[t]{2}{*}{3.} & \multirow[t]{2}{*}{ Harvesting } & $\begin{array}{l}\text { Combine } \\
\text { Harvester }\end{array}$ & 4 & 0 & $\begin{array}{c}4 \\
(100.00)\end{array}$ & 5 & 0 & $\begin{array}{c}5 \\
(100.00)\end{array}$ & 4 & 0 & $\begin{array}{c}4 \\
(100.00)\end{array}$ \\
\hline & & $\begin{array}{l}\text { Paddy } \\
\text { reaper }\end{array}$ & 9 & 2 & $\begin{array}{c}7 \\
(77.77)\end{array}$ & - & - & & - & - & \\
\hline 4. & Threshing & $\begin{array}{l}\text { Multicrop } \\
\text { Thresher }\end{array}$ & 6 & 4 & $\begin{array}{c}2 \\
(33.33)\end{array}$ & 8 & 7 & $\begin{array}{c}1 \\
(12.50)\end{array}$ & 7 & 5 & $\begin{array}{c}2 \\
(28.57)\end{array}$ \\
\hline
\end{tabular}


In all three crops, viz., paddy, maize and pigeon pea, mechanization gap and farm machinery requirement was found high for harvesting operation. Due to financial and technical non-viability, mechanization gap was high in harvesting operation. Farmers can afford to purchase implements like M B plough, cultivator, disc harrow but, they cannot afford to purchase high cost machinery like combine harvester. The results are in line with the findings of Umesh (2012). Government should provide each of this high cost machinery to a cluster of custom hiring centers.

The requirement of cultivators and rotovators was found high in all three crops for land preparation operation. Cultivator and rotovator are the primary and secondary tillage equipments. Availability of these equipments through custom hiring centers in required number based on the proportion to the cultivated area facilitates the farming community to go for mechanization.

In conclusion, mechanization gap and farm machinery requirement was found high in paddy compared to maize and pigeon pea. Compared to maize and pigeon pea, cultivation of paddy has more scope for mechanization because specific implements/ machinery are required for each operation like cage wheel for puddling and paddy transplanter for transplanting. There is a need to reduce the gap and equip the custom hiring centers with farm implements/ machinery in proportion to the total cultivated area.

\section{References}

Karale, D.S., Khambalkar, V. P., Bhende, S. M., Amale, Sharddha and Wankhede, Pranali (2008). Energy economic of small farming crop production operations. World J. of Agril. Science, 4 (4): 476-482.

Singh, Gyanendra (2006). Estimation of a mechanisation index and its impact on production and economic factors-a case study in India. Biosystems Engineering, 93(1): 99-106.

Umesh, M., 2012, Mapping of mechanization needs and gaps of rice growers in Raichur district of Karnataka. M. Sc. (Agri.) Thesis, Univ. Agric. Sci., Dharwad, Karnataka (India).

\section{How to cite this article:}

Nagarjuna Reddy, P. and Jagadeesh G. Angadi. 2018. Mechanization Gap and Assessment of Farm Mechanization Requirement for Each Operation in Different Crops. Int.J.Curr.Microbiol.App.Sci. 7(12): 1213-1216. doi: https://doi.org/10.20546/ijcmas.2018.712.151 